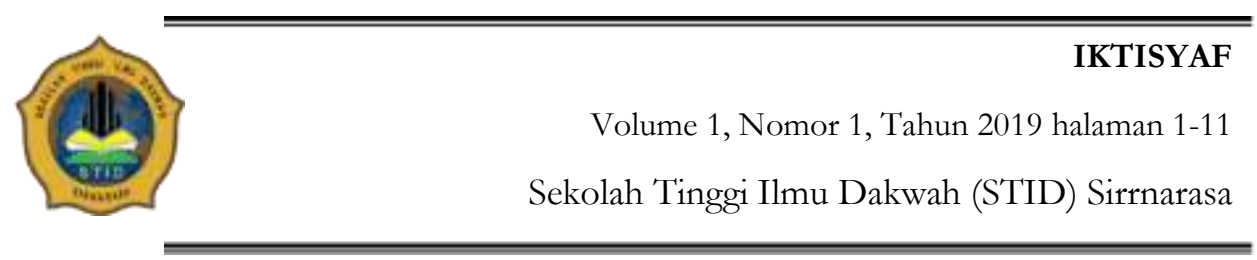

\title{
NILAI-NILAI KITAB TA’LIMUL MUTA’ALIM DALAM PESANTREN MELALUI DAKWAH FARDIYAH
}

\author{
Dadang Muliawan, Ade Abdul Kustiana \\ Komunikasi Penyiaran Islam STID Sirnarasa \\ dadang@stidsirnarasa.ac.id.
}

\begin{abstract}
ABSTRAK
Dakwah Fardiyah merupakan salah satu metode yang baik dalam tercapainya pesan seorang da'i kepada mad'u. dan salah satu pesan yang di berikan adalah Nilai-nilai dari kitab Ta'limul Muta'alim karangan Syekh az-Zarnuji, kitab ini adalah kajian penting di setiap pesantren, Kitab ini menjadi suatu pedoman bagi para santri dalam meraih keberhasilan dalam mencari ilmunya, namun tidak semudah itu dalam memahami nilai-nilai yang terdapat pada kitab ini perlu adanya suatu metode dalam penyampaian nilai-nilai yang ada pada Kitab Ta'limul Muta'alim ini, salah satu dari metode penyamnpaian nilai ini dengan dakwah fardiyah. Penelitian ini betujuan untuk mengkaji metode-metode dalam penyampaian nilai-nilai kitab ta'limul muta'alim yang dilakukan di Pesantren Sirnarasa. Upaya dari peneitian ini ditujukan Pertama, untuk mengetahui nilai-nilai yang ada pada kitab ta'limul muta'alim, Kedua, untuk mengetahui implementasi dari nilai-nilai kitab ta'limul muta'alim melalui dakwah fardiyah.Untuk menjawab pertanyaan tersebut maka menggunakan metode penelitian yang digunakan dengan jenis penelitian deskriptif kualitatif, sumber data dari Kitab Ta'limul Muta'alim dan dikuatkan dengan wawancara bersama Mudaris Pesantren Sirnarasa.Analisis yang digunakan dalam penelitian ini adalah analisis interaktif yakni Proses bergulir dan peninjauan kembali selama proses penelitian sesuai dengan fenomena dan strategi penelitian yang dipilih peneliti memberi warna analisis data yang dilakukan, namun tidak akan terlepas dari kerangka pengumpulan data, reduksi data, penyajian (display) data, dan kesimpulan/verifikasi, temuan penelitian ini menunjukkan bahwa dakwah fardiyah menjadi metode yang tepat dalam menanamkan pemahaman nilai-nilai yang ada pada kitab Ta'limul Muta'alim, karena Dakwah fardiyah terletak pada fokus perhatian yang lebih terhadap mad'u dan kesempatan memberi pengaruh lebih besar, sehingga menjadi besar pula tingkat keberhasilan mengajak orang ke jalan dakwah. Hasil dari Penelitian ini adalah sebagai berikut Nilai-nilai yang terdapat pada kitab Ta'limiul Muta'alim yakni Nilai Ta'dziman Watakriman, Nilai Semangat Juang, dan Menjauhi Sifat Malas. Implementasi dari nilai-nilai diatas adalah 1. Nilai ta'dziman watakriman dalam dakwah fardiyahnya menggunakan cara Hikmah, Mauizhah Hasanah, Mujadalah bi al-lati hiya ahsan, 2. Nilai Semangat Juang dakwah fardiyahnya dengan cara Uswah Hasanah dan Ta'aruf. 3. Nilai Menjauhi Sifat malas Dakwah fardiyahnya menggunakan cara : Tilawah, Tausiyah, Mauizhah Hasanah.
\end{abstract}

Kata Kunci: Nilai, Kitab, Dakwah Fardiyah 


\section{PENDAHULUAN}

Mempelajari adab-adab islam secara umum merupakan perkara yang sangat urgen dan memiliki kedudukan yang tinggi dalam agama Islam. Bahkan mempelajari dan memahami adab-adab menuntut ilmu sangat dianjurkan bagi para penuntut ilmu sebelum mereka mulai mempelajari ilmu-ilmu syar'i itu sendiri, yang demikian ini dikarenakan perjalanan dalam menuntut ilmu agama sangat panjang dan ilmu yang harus dipelajari sangat banyak luas, sedangkan umur manusia di dalam kehidupan dunia ini sangatlah pendek dan terbatas.

Kitab Ta'limul Muta'alim berisi banyak nilai-nilai tentang adab di dalamnya, diantaranya ada salah satu bab cara menghormati ilmu dan guru, dimana seorang santri akan meraih keberhasilan dalam menuntut ilmunya apabila menghormati dan ta'dzim pada gurunya seperti perkataan Syekh az-Zarnuji dalam karyanya kitab Ta'limul Muta'alim :

Diantara strategi Pesantren untuk menanamkan nilai nilai adab diantaranya dengan memasukannya kurikulim kajian-kajian islam yang berhubungan dengan adab tersebut, diantara kitab-kitab yang dipelajari adalah kitabTa'limul Muta'alim yang menjadi kajian wajib di Pesantren, Kitab Ta'limul Muta'alim ini menjadi kajian penting bagi pengajian hampir di seluruh Pesantren yang ada di Indonedia termasuk Pesantren Sirnarasa, Pesantren Sirnarasa yang berada di Dusun Ciceuri Desa Ciomas Kecamatan Panjalu, turut ikut berpartisipasi dalam menyiapkan generasi insan yang berakhlaqul karimah.

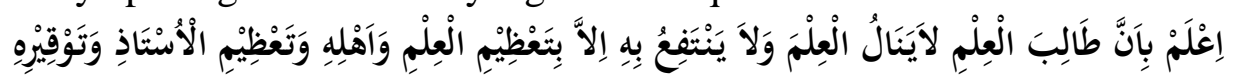

"Santri tidak akan memperoleh ilmu da tidak akan dapat mengambil manfaatnya, tanpa mau menghormati ilmu dan guru."

Dari diskripsi yang telah penulis paparkan di atas, maka penulis tertarik untuk mengkaji lebih lanjut berjudul "Nilai-Nilai Kitab Ta'limul Muta'alim Dalam Pesantren Melalui Dakwah Fardiyah" Penelitian di Pesantren Sirnarasa.

\section{LANDASAN TEORI}

\section{A. Pengertian Nilai}

Nilai berasal dari Bahasa Latin Vale're yang artinya berguna, mampu akan, berdaya berlaku, sehingga nilai diartikan sebagai sesuatu yang dipandang baik, bermanfaat dan paling benar menurut keyakinan seseorang atau sekelompok orang. Nilai adalah kualitas suatu hal yang menjadikan hal itu disukai, diinginkan, dikejar, dihargai, berguna dan dapat membuat orang yang menghayatinya menjadi bermartabat

Dari analisis Bertens dapat dikatakan nilai adalah hal yang subyektif dalam memberikan apresiasi (penilaian) terhadap obyek. Sebuah obyek akan dianggap memiliki nilai tergantung pada subyek yang memandang. Misalnya, musik punk akan memiliki nilai keindahan apabila didengarkan dan dinikmati oleh orang yang menyukai musik punk, Sedangkan orang yang tidak menyukai musik punk akan menganggap musik punk tidak memiliki nilai apa-apa (non-nilai).

Sedangkan Prof. Notonegoro membagi nilai menjadi tiga kategori :

1) Nilai Matrial adalah nilai yang berguna bagi unsur jasmani manusia. Seperti contoh, makanan, pakaian, rumah, dll.

2) Nilai Vital adalah segala sesuatu yang berguna untuk aktivitas manusia. Contohnya, bagi pelajar buku memiliki nilai vital, karena adalah benda yang penting bagi aktifitas dalam pembelajaran.

3) Nilai kerohaniaan adalah segala sesuatu yang berguna bagi rohani manusia. Nilai kerohanian dapat dibagi menjadi empat macam, yaitu:

a) Nilai kebenaran, bersumber pada unsur rasio manusia, budi, dan cipta. 
b) Nilai keindahan, bersumber pada unsur rasa atau intuisi.

c) Nilai moral, bersumber pada kehendak manusia atau kemauan (karsa, etika).

d) Nilai religi, bersumper pada nilai ketuhanan, merupakan nilai kerohanian yang tertinggi dan mutlak. Nilai ini bersumber dari keimanan dan keyakinan kepada Tuhan. Nilai religi bersumber pada penghayatan yang bersifat transedental, dalam usaha manusia untuk memahami arti dan maena kehadirannya di dunia. Nilai ini berfungsi sebagi sumber moral yang dipercayai sebagi rahmat dan rida Tuhan.

Dengan demikian, dari apa yang telah dipaparkan, penulis mengambil kesimpulan bahwa nilai adalah harga dan guna dari kualitas obyek (benda) yang diberikan oleh subyek (penilai). Sebuah benda (obyek) akan bernilai jika memiliki kegunaan. Baik kegunaan yang bersifat jasmani maupun kegunaan yang bersifat rohani.

\section{B. Dakwah dan Urgensi Dakwah Fardiyah}

Secara umum, dakwah adalah ajakan atau seruan kepada yang baik dan yang lebih baik. Dakwah mengandung ide tentang progresivitas, sebuah proses terus-menerus menuju kepada yang baik dan yang lebih baik dalam mewujudkan tujuan dakwah tersebut. Dengan begitu, dalam dakwah terdapat suatu ide dinamis, sesuatu yang terus tumbuh dan berkembang sesuai dengan tuntunan ruang dan waktu.sementara itu dakwah dalam prakteknya merupakan kegiatan untuk mentransformasikan nilai-nilai agama yang mempunyai arti penting dan berperan langsung dalam pembentukan persepsi umat tentang berbagai nilai kehidupan.

\section{C.Pesantren}

Istilah pesantren di Indonesia lebih popular dengan sebutan Pondok pesantren, lai halnya dengan pesantren, pondok berasal dari kata Bahasa Arab yang berarti hotel, asrama, rumah, dan tempat tinggal sederhana.

Dalam ulasannya mengenai pesantren. Zamakhsyari Dhofier mengemukakan lima unsur pokok yang menjadi elemen dasar dari tradisi pesantren, yakni pondok, masjid, santri, pengajaran kitab-kitab islam klasik, santri dan kiai. Dengan demikian, unsur-unsur tradisi pesantren dapat dikategorikan lagi menjadi tiga kelompok :

a. Sarana perangkat keras : Pondok dan Masjid

Dalam suatu pesantren, pondok dan masjid merupakan dua bangunan yang sangat penting. Pondok pada dasarnya adalah asrama Pendidikan Islam tradisional di mana para santri tinggal Bersama dan mendapat bimbingan dari kiai. Pondok, asrama bagi santri, ini sekaligus menjadi ciri khas tradisi pesantren yang membedakannya dengan sistem Pendidikan tradisional lainnya di masjid-masjid, surau, bahkan madrasah pada umumnya.

b. Kiai dan santri

Berbicara tentang seorang pimpinan dalam pondok pesantren tidak terlepas daripada sosok seorang kiai. Pada kalangan pesantren kiai merupakan actor utama. Kiailah yang merintis pesantren, mengasuh, menentukan mekanisme belajar dan kurikulum, serta mewarnai pesantren dalam kehidupan sehari-hari sesuai dengan keahlian dan kecenderungan yang dimilikinya. Karena itu, karakteristik pesantren dapat diperhatikan melalui profil kiainya.

Menurut pengertian yang dipakai dalam lingkungan orang-orang pesantren, seorang alim hanya bisa disebut kyai bilamana memiliki pesantren dan santri yang tinggal dalam pesantren untuk mempelajari kitab-kitab Islam klasik. Oleh karena itu 
santri merupakan elemen penting dalam suatu lembaga pesantren. Perlu diketahui bahwa, menurut tradisi pesantren santri terdiri dari dua kelompok santri:

1) Santri Mukim

Santri Mukim yaitu murid-murid yang berasal dari daerah yang jauh dan menetap dalam kelompok pesantren. Santri mukim yang paling lama tinggal di pesantren bisaanya merupakan satu kelompok tersendiri yang memang bertanggung jawab mengurusi kepentingan pesantren sehari-hari mereka juga memikul tanggung jawab mengajar santri-santri muda tentang kitab-kitab dasar dan menengah.

2) Santri Kalong

Santri kalong yaitu murid -murid berasal dari desa-desa sekitaran pesantren, bisaanya tidak menetap dalam pesantren. Untuk mengikuti pelajarannya di pesantren, mereka bolak-balik (nglaju) dari rumahnya sendiri. Bisaanya perbedaan antara pesantren besar dan pesantren kecil dapat dilihat dari komposisi santri kalong. Semakin besar sebuah pesantren, semakin besar jumlah santri mukimnya. Dengan kata lain, pesantren kecil memiliki banyak santri kalong daripada santri mukim.

Tujuan utama para santri untuk berguru ke pesantren tidak lain adalah belajar agama. Pelajaran-pelajaran agama biasanya didapat dari menggali kitab-kitab Islam klasik yang memang tersedia banyak di pesantren.

\section{METODE PENELITIAN}

Jenis penelitian kali ini adalah penelitian deskriptif kualitatif. Penelitian tersebut adalah penelitian yang datanya kualitatif. Data yang disampaikan dalam bentuk verbal dimana lebih menekankan pada persoalan kontekstual dan tidak terikat dengan perhitungan angka-angka, ukuran yang bersifat empiris. Data umumnya dalam bentuk narasi, gambar-gambar. Data dapat diperoleh melalui observasi, wawancara, rekaman dan lain sebagainya.

Metode deskriptif adalah suatu metode dalam meneliti status sekelompok, manusia suatu objek, suatu set kondisi, suatu sistem pemikiran, ataupun suatu kelas peristiwa pada masa sekarang. Tujuan dari penelitian deskriptif ini adalah untuk membuat deskripsi, gambaran atau lukisan secara sistematis, faktual dan akurat mengenai fakta-fakta, sifat-sifat serta hubungan antarfenomena yang diselidiki.

\section{ANALISIS HASIL PENELITIAN}

\section{A. Nilai-Nilai Pada Kitab Ta'limul Muta'alim yang telah dikaji di Pesantren Sirnarasa.}

Pada isi bab ini penulis akan memaparkan nilai-nilai yang didapat pada kitab Ta'limul Muta'alim yang telah dikaji di Pesantren Sirnarasa, Banyak sekali nilai nilai yang terdapat dalam kitab Ta'limul Muta'alim, oleh karena itu kitab ini adalah panduan untuk seorang santri dalam meraih keberhasilan dalam mencari ilmunya.

Nilai-nilai yang terdapat pada kitab ta'limul muta'alim diantaranya sebagai berikut:

1. Nilai Ta'dziman Watakriiman ilaa mu'allim (Bentuk pengagungan, penghormatan seorang murid kepada guru). Termasuk pada pasal cara menghormati ilmu dan guru.

Nilai Ta'dziman Watakriiman Ilaa Mu'allim merupakan salah satu diantara nilai-nilai yang terdapat pada kitab Ta'limul Muta'alim, yang termasuk pada pasal "cara menghormati ilmu dan guru" Seorang pelajar tidak akan mampu dan tidak akan mendapat ilmu yang manfaat dan barokah kalau tidak ada ta'dzim dan takrim penghormatan dan pengagungan murid kepada kepada guru, murid boleh saja dikategorikan pintar, cerdas mudah menghafal, banyak hafalanya tapi tidak diiringi ta'dziman watakriman kepada guru, nanti setelah keluar dari pesantren banyak yang 
menemui jalan buntu dalam arti tidak manfaat ilmunya jangankan untuk disebar kepada orang lain untuk diri sendiri saja susah, dan nilai yang diserap oleh santri adalah nilai dari penghormatan dan pengagungan terhadap guru, bukan hanya dalam penngajian saja tapi berbakti dan diaplikasikan di keseharian dalam kehidupannya.

Sebagaimana yang dikatakan oleh imam Asy Syairazy dalam buku terjemah Ta'limul Muta'alim berkata :

"Guru-guruku berkata: "Barangsiapa yang ingin anaknya menjadi orang alim, maka dia harus menghormati para ahli fiqih. Dan memberi sedekah pada mereka. Jika ternyata anaknya tidak menjadi orang alim, maka cucunya yang akan menjadi orang alim."

Syekh imam az-Zarnuji juga menegaskan hal yang termasuk menghormati guru ialah :

"Hendaknya seorang murid tidak berjalan di depannya, tidak duduk di tempatnya, dan tidak memulai bicara padanya kecuali dengan ijinnya, hendaknya tidak banyak bicara di hadapan guru, tidak bertanya sesuatu bila guru sedang capek atau bosan, harus menjaga waktu, jangan mengetuk pintunya tapi sebaliknya menunggu sampai beliau keluar"

Al Qadhi Fahruddin adalah seorang imam di daerah Mawra yang sangat dihormati oleh para pejabat negara beliau berkata :

"Aku mendapat kedudukan ini karena aku menghormati guruku, Abi Yazid Addabusi, aku selalu melayani beliau, memasak makanannya, dan aku tak pernah ikut makan bersamanya."

2. Nilai Semangat Juang

Al-jidd (semangat juang, tekad yang kuat, dedikasi yang tinggi, dan kesungguhan) "kesungguhan itu dapat mendekatkan sesuatu yang jauh, dan bisa membuka pintu yang terkunci'Dalam arti lain dari kesungguhan akan mendatangkan yang jauh yang susah jadi mudah, akan mendatangkan yang jauh dan bisa membuka pintu pintu rizki yang terkunci akan terbuka dan kebaikan pun akan terbuka.

Seperti yang dikatakan dalam karangan Syekh az-Zarnuji pada pasal "Kesungguhan Dalam Belajar Ketekunan dan Cita-cita" bahwasanya seorang santri harus bersungguh-sungguh dalam belajar, harus tekun seperti yang diisyaratkan dalam Al-Qur'an : "Dan orang-orang yang berjihad atau berjuang sungguhsungguh untuk mencari (keridhaanku), maka benar-benar Aku akan tunjukkan mereka pada jalan-jalann menuju keridhaan-Ku." Dikatakan barangsiapa bersungguh-sungguh mencari sesuatu tentu akan mendapatkannya. Dan siapa saja yang mau mengetuk pintu, dan maju terus, tentu bias masuk.

Ustadz Sadiduddin mengalunkan syair gubahan Imam Syafi'I kepadaku : AlJiddu yudni kulla amrin Syasi'in waljiddu yaftahu kulla baabin muglain waahaqqu kholqillahi bilhammimru'un Dzuu himmatin yubla bi'aisyin dloyyiqin Waminaddaliili 'alal qodloiwahukmihi bu'sulabiibi wathoibu 'aisyil ahmaqi lakinna man ruziqol hijaahurimal gina dliddaani yaftariqooni ayya tafarruqi yang artinya "Kesungguhan itu dapat mendekatkan sesuatu yang jauh, dan bisa membuka pintu yang terkunci, sungguh sangat banyak orang yang bercita-cita luhur bersedih, karena diuji dengan kemiskinan. Barangkali sudah menjadi suratan takdir dan keputusan Allah, bahwa banyak orang cerdas tapi miskin dan banyak orang bodoh yang kaya raya. Dan kedua hal tersebut tidak bisa dikumpulkan. 
Penyusun kitab ini berkata bagiku, cukup menarik makna syair yang berbunyi, "Barangsiapa ingin meraih apa yang dicita-citakan, maka ia harus menjadikan waktu malamnya sebagai kendaraan untuk mengejar cita-citanya. Jangan banyak makan agar kamu tidak ngantuk. Hal itu jika anda benar-benar ingin mencapai kesempurnaan.

Ada yang berkata bahwa mengurangi tidur malam untuk beribadah itu menggembirakan hati di siang hari. Santri harus mengulang-ulang pelajarannya pada awal malam dan akhir malam. Yaitu antara Isya' dan waktu sahur, karena saat-saat tersebut diberkati.

Para pelajar harus memanfaatkan masa mudanya untuk bersungguh-sungguh dalam menuntut ilmu. Perhatikan bait syair ini, "Dengan kadar kerja kerasmulah kamu akan diberi apa yang menjadi cita-citamu. Orang ynag ingin sukses, harus sedikit mengurangi tidur malam. Gunakan masa mudamu sebaik-baiknya, karena masa muda adalah kesempatan yang tidak akan pernah terulang."

3. Nilai Menjauhi Sifat Malas

Malas adalah sumber mala petaka, bencana, kesusahan, kesedihan, penderitaan keterpurukan yang semuanya itu itu muncul dari malas seperti yang diungkapkan pula oleh Syekh az-Zarnuji "Kammin hayaa in wakam ajzin wakam nadamin jammin tawalladalil insani min kasalin" yang artinya : Semua kesusahan penderitaan keterpurukan itu numpuk menghinggapi manusia karena sumber utamanya adalah malas.

Menurut Abah Aos yang merupakan Sesepuh di Pesantren Sirnarasa mengatakan bahwasanya : "Kalau ingin sukses termasuk sukses ilmu harus naik kuda atau kudaek", Kudaek adalah Bahasa sunda jika diterjemahkan ke dalam bahasa Indonesia menjadi keinginan kuat dalam melakukan sesuatu, atau diartikan juga kemampuan dalam melakukan sesuatu, maka sebaiknya tinggalkanlah sifat kemalasan, mengutip juga perkataan dalam kitab Ta'limul Muta'alim yang berbunyi "Al-a'mal hayyinun alal mujjidi wa'a'mal sho'bun 'alal kaslan" yang artinya : amal-amal apapun akan terasa mudah bagi orang yang punya semangat, dan amal itu akan terasa sulit bagi orang yang malas, untuk itu dalam kitab Ta'limul Muta'alim ditanamkan betapa pentingnya kita menjauhi sifat malas.

Banyak ayat Al-qur'an yang menceritakan tentang kemalasan itu sendiri diantaranya ada pada Q.S An-Nisa : 42 yang berbunyi :

Sesungguhnya orang-orang munafik itu menipu Allah, dan Allah akan membalas tipuan mereka. Dan apabila mereka berdiri untuk shalat mereka berdiri dengan malas. Mereka bermaksud riya' (dengan shalat) di hadapan manusia. Dan tidaklah mereka menyebut Allah kecuali sedikit sekali.

Dan juga terdapat pada Q.S At-Taubah :54 yang berbunyi :

Dan tidak ada yang menghalangi mereka untuk diterima dari mereka nafkah-nafkahnya melainkan karena mereka kafir kepada Allah dan RasulNya dan mereka tidak mengerjakan sembahyang, melainkan dengan malas dan tidak (pula) menafkahkan (harta) mereka, melainkan dengan rasa enggan.

\section{B. Implementasi Nilai-nilai Kitab Ta'limul Muta'alim dalam Pesantren Melalui Dakwah Fardiyah}

Sebelum lanjut ke pembahasan mengenai implementasi bagaimana apabila nilainilai Ta'limul Muta'alim di sampaikan dengan cara Dakwah Fardiyah, perlu diketahui bahwasanya unsur-sunsur dari dakwah itu sendiri terdiri dari beberapa bagian : 
1. Da'i, Da'i pada pembahasan kali ini adalah mudaris di Pesantren Sirnarasa.

2. Mad'u, Untuk Sasaran Dakwah dari Da'i itu sendiri adalah Santri yang bermukim di Pesantren Sirnarasa.

3. Metode, Untuk metodenya dalam bentuk Dakwah Fardiyah

4. Materi/Pesan Dakwah, Materi yang disampaikannya adalah Nilai-nilai Kitab Ta'limul Muta'alim

5. Media Dakwah, Media dalam dakwah adalah Kitab Ta'limul Muta'alim karangan Syekh az-Zarnuji.

Adapun sarana dakwah fardiyah banyak macamnya yang dapat digunakan secara bertahap sesuai dengan tahapan pendekatan da'i terhadap individu mad'unya. Menurut Aripudin Ada beberapa metode dalam dakwah fardiyah yakni :

1. Hikmah pendekatan ilmiah, bentuk tindakannya yaitu berkata jujur, berbicara sesuai objeknya, sistematis, dukungan fakta, singkat dan padat.

2. Mauizhah Hasanah dengan menjadi seorang teladan yang baik, memberikan pelajaran yang benar tepat untuk anak-anak dan orang awam (umum).

3. Mujadalah bi al-lati hiya ahsan yaitu dengan berdialog, berdebat, dan diskusi tepat dilakukan ketika berhadapan dengan kaum intelek terpelajar, para alim, dan kaum pembantah.

4. Ta'aruf maksudnya yaitu pertukaran budaya positif antara satu sama lain.

5. Ishlah artinya perbaikan yang mana sikap moderat sangat dituntut dalam metode ini.

6. Tilawah yaitu pembacaan kebenaran universal.

7. Taushiyah dengan cara saling berwasiat dalam kebaikan termasuk didalamnya kritik konstruktif.

8. Ta'lim yaitu pembelajaran yang dapat dilakukan dengan cara presentasi dan dialog.

9. Uswah hasanah yaitu dengan cara memberikan percontohan yang baik menyatu didalamnya bahwa ucapan dan perbuatan mesti seirama dan sama.

Implementasi nilai-nilai pada kitab ta'limul muta'alim yang telah dipelajari okeh para santri di Pesantren Sirnarasa ini sebagai berikut:

1. Nilai Ta'dziman Watakriman

Adapun dakwah fardiyah dalam penyampaian nilai tersebut rujukanya adalah dengan Q.S An-Nahl ayat 125 yang artinya:

"Serulah (manusia) kepada jalan Tuhan-mu dengan hikmah dan pelajaran yang baik dan bantahlah mereka dengan cara yang baik. Sesungguhnya Tuhanmu Dialah yang lebih mengetahui tentang siapa yang tersesat dari jalan-Nya dan Dialah yang lebih mengetahui orang-orang yang mendapat petunjuk.

Dari terjemahan ayat diatas dapat dirincikan lagi ke dalam beberapa bagian :

a. Dengan cara Hikmah

M. Abduh berpendapat bahwa, Hikmah adalah mengetahui rahasia dan faedah dalam tiap-tiap hal. Dalam konteks ushul fiqh istilah hikmah dibahas ketika ulama ushul membicarakan sifat-sifat yang dijadikan ilat hukum. Orang yang memiliki hikmah disebut al-hakim yaitu orang yang memiliki pengetahuan yang paling utama dari segala sesuatu. Sebagai metode dakwah Hikmah diartikan bijaksana, akal budi yang mulia, dada yang lapang, hati yang bersih, dan menarik perhatian orang pada agama dan Tuhan.

Ibnu Qayim berpendapat bahwa pengertian hikmah yang paling tepat adalah pengetahuan tentang kebenaran dan pengalamannya, ketepatan dalam perkataan dan pengalamannya. 
Dari beberapa pengertian diatas dapat dipahami bahwa Hikmah adalah merupakan kemampuan dan ketepatan da'i dalam memilih, memilah dan menyelaraskan teknik dakwah dengan kondisi objektif mad'u. Hikmah merupakan kemampuan da'i dalam menjelaskan doktrin-doktrin islam serta realitas yang ada dengan argumentasi logis dan bahasa yang komunikatif. Oleh sebab itu Hikmah sebagai sebuah sistem yang menyatukan antara kemampuan teoritis dan praktis dalam berdakwah

Cara ini bisa disebut komunikasi hati ke hati, bentuk ini dikomunikasikan ketika seseorang melakukan praktek ibadahnya, dan saling keterkaitanya dengan ruh guru dengan murid, Maka dengan cara ini ta'dzim murid dan takrim murid terhadap guru akan lebih di rasa dan di aplikasikan.

b. Mauizhah hasanah (Tauladan yang baik)

Pelajaran yang baik ini dilakukan banyak cara untuk menyampaikanya yakni berupa tindakan contoh yang dilakukan oleh guru dengan mempraktekanya sikap ta'dzim terhadap gurunya lagi. Jadi seorang santri melihat langsung aksi yang dilakukan oleh gurunya sendiri. Cara-cara diatas termasuk kedalam kategori komunikasi secara non verbal, dimana komunikasi nonverbal ini merupakan komunikasi yang menggunakan pesan pesan nonverbal. Istilah nonverbal biasanya digunakan untuk melukiskan semua peristiwa komunikasi di luar kata-kata terucap dan tertulis.

c. Mujadalah bi al-lati hiya ahsan (Bantahan yang baik)

Bantahan dalam arti disini dalam konteks seorang guru melakukan pembicaraan yang baik dan dengan mengapresiasi dari segala macam pembahasan yang dilontarkanya.

Menurut Ust. Ahmad Fauzi Zaenal Abidin salah satu mudaris Pesantren Sirnarasa dalam pemberian metode yang dilakukan untuk penanaman nilai-nilai kitab Ta'limul Muta'alim terhadap santri diantaranya adalah, menggunakan metode komunikasi interpersonal pendekatan dengan santri, ngajak ngobrol berdua dan melakukan perbincangan yang hangat menyapa dan mencoba memasukan nilai-nilai yang terdapat pada kitab Ta'limul Muta'alim itu sendiri. Selain itu informan mencoba melakukan dalam hal tindakan non verbalnya melalui tindakan sebagai salah satu contohnya implementasi dari nilai-nilai kitab ta'limul muta'alim cara menghormati ilmu, santri harus menyimpan kitab diatas segalanya kecuali alquran.

Sedangkan dalam komunikasi verbalnya sang kiai atau mudaris melakukan pendekatan dengan melakukan pembicaraan pembicaraan yang menjurus kepada nilai-nilai tersebut seperti menasihatinya bahwasanya menghormati dan ta'dzim kepada guru itu penting dan wajib kita laksanakan.

2. Nilai Semangat Juang

Penerapan nilai yang dilakukan oleh para pengajar di Pesantren dalam penerapan nilai ini adalah sebagai berikut :

Dengan mengadakannya kegiatan yang membangkitkan semangat para santri dan lebih menekankan pada cinta tanah air yakni :

a. Dengan metode Uswah Hasanah

"Santri Bela Negara" Pelaksanaan kegiatan yang diadakan dalam satu tahun sekali, diantaranya salah satu metode dari Uswah Hasanah bertepatan pula dengan hari santri nasional pada tanggal 22 Oktober, selain itu mengerahkan para santri menuju nilai-nilai yang berhubungan dengan semangat juang, yakni membiasakannya disiplin akan melakukan sesuatu, seperti contoh ajakan untuk sholat berjamaah di Masjid, yang dikomunikasikan melalui media di microphone 
kalau telat akan dikenai sanksi atau hukuman, hukuman disini berupa dengan mencukur rambut, dan olahraga bending.

b. Dengan metode Ta'aruf

Ta'aruf secara bahasa berasal dari kata "Arafa" yang berarti tah atau kenal.Tahu atau kenak di sini maksudnya mengetahui dan mengenal denga tandatanda yang membuatnya bisa membedakan antara satu dengan yang lainnya. Saling mengenal dengan tanda-tanda atau ciri-ciri orang, baik lewat mata, cara berbicara, watak dan karakter.Dalam kehidupam manusia, saling mengenal atau ta'aruf memerlukan waktu yang panjang. Dalam ta'aruf akan terjadi tukar informasi dan pengalaman. Pada saat itu terjadi proses pengaruhmempengaruhi.Maka dari itu hal ini pula yang dilakukan oleh para Mudaris terhadap Santri di Pesantren Sirnarasa, dengan cara ini proses penukaran pesan dapat tersampaikan lebih mendalam antara santri dan pengajar di Pesantren Sirnarasa.

Tahapan dalam penyampaian nilai ini dengan menggunakan metode ta'aruf sebagai berikut : perkenalan di awal Pengajian, Pertemuan tatap muka di kelas ngaji tiap 3x sehari dan saling percaya satu sama lain dengan mengedepankan komitmen satu sama lain untuk tujuan yang sama yakni keberhasilan dalam belajar.

Menurut Joseph A. DeVito, prinsip-prinsip komunikasi interspersonal adalah sebagai berikut :Komunikasi interpersonal adalah suatu proses transaksional. Komunikasi interpersonal adalah sebuah proses, atau kejadian yang berkelanjutan, dimana masing-masing elemen saling bergantung satu sama lain. Komunikasi interpersonal secara konstan terus terjadi dan mengalami perubahan. Agar dapat memahami gambaran komunikasi interpersonal sebagai proses transaksional maka model komunikasi transaksional dapat menjadi jawabannya.

3. Nilai Menjauhi Sifat Malas

Sudah dijelaskan pada poin di atas bahwasanya malas merupakan sumber kesialan, malapetaka sebagaimana sudah dijelaskan pada poin diatas, Nilai menjauhi sifat malas ini tertera pada pasal kedua menurut Ridwan Alfian salah satu mudaris di Pesantren Sirnarasa mengungkapkan dalam caranya beliau untuk menanamkan nilai dari sifat malas ini adalah dengan :

a. Dengan cara Tilawah yakni berupa Mengemukakan penjelasan ayat Al-qur'an dan Hadist yang berkaitanya dengan malas.

b. Tausiyah yakni Menceritakan hikayat dan imbalan tentang orang-orang saleh yang menjauhi sifat malas.

c. Mauizhah Hasanah dengan cara ini informan Mengajak santri mengerjakan kegiatan hal-hal positif seperti: berziaroh ke makam orang-orang yang saleh, dan juga kegiatan positif lainya yakni Mengajak untuk melaksanakan salat malam dengan dibarengi oleh kita.

Ungkapan lain dikemukakan oleh Ahmad Fauzi Zaenal Abidin mengatakan bahwa :

Dengan cara Tausiyah Dalam penyampaian nilai ini, tertuju kepada santri yang sudah mulai mengeluh dalam mengaji dan tidak nyaman di pesantrenya, diantaranya dengan menasihatinya : bahwasanya di rumah itu ada yang menanti untuk kedatangan anaknya yang dirasa udah bisa menguasai segala bidang ilmu, karena dirumah itu orang tua lagi berjuang mati-matian demi kesuksesan yang akan diraih oleh anaknya sendiri, dan kita sendiri sebagai anaknya bukan untuk dan berleha-leha bersantai akan tetapi untuk berjuang demi membahagiakan orangtuannya. 


\section{KESIMPULAN}

1. Nilai yang terdapat pada kitab Ta'limul Muta'alim yang telah dikaji di Pesantren Sirnarasa:

a. Nilai Ta'dziman Watakriiman

b. Nilai Semangat Juang

c. Nilai Menjauhi Sifat Malas

2. Implemetasi Nilai-nilai Kitab Ta'limul Muta'alim dalam Pesantren Melalui Dakwah Fardiyah

a. Nilai Ta'dziman Watakriman Dakwah fardiyahnya dengan hal sebagai berikut :

1. Hikmah

2. Mauizhah Hasanah

3. Mujadalah bi al-lati hiya ahsan

b. Nilai Semangat Juang dalam penanaman nilai ini menggunakan cara dakwah fardiyah sebagai berikut :

1. Uswah Hasanah

2. Ta'aruf

c. Menjauhi Sifat malas dalam dakwah fardiyahnya menggunakan cara sebagai berikut :

1. Tilawah

2. Mauizhah hasanah

3. Tausiyah

\section{SARAN}

1. Bagi Pengajar/ Assatid Pesantren Sirnarasa perlu ditingkatkan dalam inovasinya dalam dakwah fardiyah.

2. Jaga selalu hubungan yang baik antara sesame Assatid,Pengurus dan santri tidak lupa juga dengan menjada komunikasi yang intens dengan orangtua santri

3. Unruk Pesantren Sirnarasa lanjutkan kurikulum yang menjadikan Ta'limul Muta'alim sebagai materi pelajaran di Pesantren, usahakan jangan seminggu sekali akan tetapi dimasukan kepada pelajaran sehari-hari di kelas. Biar dari pembelajaran

\section{DAFTAR PUSTAKA}

Ali Abdul Halim Mahmud. 1995 Dakwah Fardiyah, Metode Membentuk Pribadi Muslim. Jakarta: Gema Insani Press

Al-qur'an dan terjemahannya. 2008. Departemen Agama RI. Bandung : Diponegoro

Asep Saeful Muhtadi. 2012. Komunikasi Dakwah, Teori, Pendekatan, dan Aplikasi Bandung:Simbiosa Rekatama Media.

E. Mulyasa. 2003 Kurikulum Berbasis Kompetensi Konsep dan Implementasi. Bandung : PT Remaja Rosdakrya.

Elvinaro Ardianto, Bambang Q-Anees. 2014. Filsafat Ilmu Komunikasi. Bandung: PT Remaja Rosdakarya.

Enjang, Aliyudin. 2009. Dasar-dasar Ilmu Dakwah. Bandung: Widya Padjadjaran

Fathi Yakan. 2004. Problematika Dakwah dan Para Dai. Solo: Era Intermedia.

Hasbullah, 2012 Dasar-Dasar Ilmu Pendidikan. Jakarta : Raja Grafindo Persada

John M. Echols, Hasan Sadily. 2005. Kamus Lengkap Inggris Indonesia. Jakarta : Gramedia.

Kompri. 2018. Manajemen dan Kepemimpinan Pondok Pesantren. Jakarta: Prenadamedia Group.

Kustadi Suhandang. 2013 Ilmu Dakwah. Cet.1. Bandung : PT. Remaja Rosdakarya,

Moh Nazir. 2017. Metode Penelitian. Bogor : Penerbit Ghalia Indonesia

Mohammad. E. Ayub. 1996 Manajemen Masjid, Jakarta : Gema Insani Press, 
Muri Yusuf. 2014 Metode Penelitian Kuantitatif,Kualitatif \& Penelitian Gabungan. Jakarta: Kencana

Ngalimun. 2016. Ilmu Komunikasi Sebuah Pengantar Praktis. Yogyakarta: Pustaka Baru Press.

Nogarsyah Moede. 2002. Buku Pintar Dakwah. Jakarta : INTIMEDIA \& LADANG PUSTAKA.

Onong Uchjana Effendy. 2003. Ilmu, Teori dan Filsafat Komunikasi. Bandung : PT. Citra Aditya Bakti.

Onong Uchjana Effendy. 2006. Hubungan Masyarakat Suatu Studi Komunikologis. Bandung : PT Remaja Rosdakarya.

Profil Yayasan Sirnarasa Cisirri (YSC) Komplek Pesantren Sirnarasa Dsn. Ciceuri Ds. Ciomas. Kec. Panjalu (46264), Kab. Ciamis, Jawa Barat

Silfia Hanani. 2017. Komunikasi Antarpribadi Teori dan Praktik. Yogyakarta : Ar-Ruzz Media.

Suluk Bacaan Para Salik Amaliyah Lengkap Thoriqot Qodiriyyah Naqsyabandiyyah Ma'had Suryalaya

Sutarjo Adisusilo. 2013 Pembelajaran Nilai Karakter Konstruktivisme Dan VCT Sebagai Inovasi Pendekatan Pembelajaran Afektif . Jakarta: Rajawali Pers,

Suwartono. 2014. Dasar-Dasar Metodologi Penelitian. Yogyakarta : CV ANDI OFFSET.

Tata Sukayat. 2009. Quantum Dakwah. Jakarta: Rineka Cipta,

Wahyu Ilaihi. 2013 Konsep Dasar Komunikasi Dakwah. Cet.II Bandung: PT Remaja Rosdakarya.

Zamkahsyari Dhofier. 2011. Tradisi Pesantren Studi Pandangan Kyai dan Visinya Mengenai Masa Depan Indonesia. Jakarta:LP3ES 